\title{
Functional characterization of peroxisome biogenic proteins Pex5 and Pex7 of Drosophila
}

Francesca Di Cara, Richard A. Rachubinski and Andrew J. Simmonds

Department of Cell Biology, Faculty of Medicine and Dentistry, University of Alberta, Edmonton, Alberta, Canada, T6G 2H7 andrew.simmonds@ualberta.ca 


\section{ABSTRACT}

Peroxisomes are ubiquitous membrane-enclosed organelles involved in lipid processing and reactive oxygen detoxification. Mutations in human peroxisome biogenesis genes (Peroxin, PEX) cause progressive developmental disabilities and, in severe cases, early death. PEX5 and PEX7 are receptors that recognize different peroxisomal targeting signals called PTS1 and PTS2, respectively, and traffic proteins to the peroxisomal matrix. We characterized mutants of Drosophila melanogaster Pex5 and Pex7 and found that adult animals are affected in lipid processing. Moreover, Pex5 mutants exhibited severe developmental defects in the embryonic nervous system and muscle, similar to what is observed in humans with Pex5 mutations, while Pex7 fly mutants were weakly affected in brain development, suggesting different roles for Pex7 in fly and human. Of note, although no PTS2-containing protein has been identified in Drosophila, Pex7 from Drosophila can function as a bona fide PTS2 receptor because it can rescue targeting of the PTS2containing protein Thiolase to peroxisomes in PEX7 mutant human fibroblasts. 


\section{INTRODUCTION}

Peroxisomes have long been known to be involved in a variety of important biochemical functions, most notably lipid metabolism and the detoxification of reactive species (Bowers, 1998; Deduve, 1965; Nguyen et al., 2008; Wanders and Waterham, 2006). Recent evidence has shown peroxisomes to have important roles in development, immune signaling and viral maturation. Peroxisome biogenesis genes (Peroxin, PEX) are for the most part conserved across the breadth of eukaryotes (Platta and Erdmann, 2007; Schrader and Fahimi, 2006). Thirteen $P E X$ genes are required for peroxisome biogenesis in humans, and mutations in these genes cause the peroxisome biogenesis disorders (PBDs), which manifest as heterogeneous syndromes with varied developmental defects (Braverman et al., 2013). PEX5 and PEX7 act as receptors that recognize cis-acting signals called peroxisome targeting signals (PTS) in soluble peroxisomal proteins to traffic them from the cytosol to the peroxisome matrix (Smith and Aitchison, 2013) (Ito et al., 2007; Klein et al., 2001; Purdue et al., 1997). PEX5 and PEX7 homologues are found across the eukaryota, including kinetoplastids, yeasts, plants and mammals (Kanzawa et al., 2012; Kragler et al., 1998; Lazarow, 2006; Matsumura et al., 2000; McCollum et al., 1993; Purdue et al., 1997; Rehling et al., 1996; Woodward and Bartel, 2005). PEX5 recognizes the C-terminal PTS1 with the canonical sequence Ser-Lys-Leu (SKL), while PEX7 recognizes an N-terminal nonapeptide PTS2 with the consensus sequence $(\mathrm{R} / \mathrm{K})(\mathrm{L} / \mathrm{V} / \mathrm{I}) \mathrm{X}_{5}(\mathrm{H} / \mathrm{Q})(\mathrm{L} / \mathrm{A})$ (Ito et al., 2007; McCollum et al., 1993; Rehling et al., 1996; Shimozawa et al., 1999). Mutation of PEX5 gives rise to Zellweger syndrome, while mutation of $P E X 7$ gives rise to Rhizomelic Chondrodysplasia Punctata Type 1 (RCDP1) (Purdue et al., 1997). 
Mutation of Drosophila Pex genes is linked to a range of phenotypes, including lethality (Pex1, Pex3, Pex19) and male sterility (Pex16) (Beard and Holtzman, 1987; Bulow et al., 2018; Chen et al., 2010; Faust et al., 2014; Mast et al., 2011; Nakayama et al., 2011). In Drosophila S2 cells, knock down of Pex5 transcript reduces targeting of PTS1containing proteins to peroxisomes function, while depletion or overexpression of Pex7 transcript led to smaller or larger peroxisomes, respectively, than normal (Baron et al., 2016). However, the actual function of Drosophila Pex7 remains unclear, as no bona fide peroxisomal PTS2-containing protein has been identified in Drosophila; fly homologues of peroxisomal proteins trafficked by the PTS2/PEX7 import pathway, e.g. peroxisomal Thiolase, use the PTS1/Pex5 pathway in Drosophila (Baron et al., 2016; Faust et al., 2012).

Here we show that Drosophila Pex5 mutants exhibited severe developmental defects in the embryonic nervous system and muscle, similar to what is observed in Zellweger syndrome patients with PEX5 mutations. Pex7 fly mutants exhibited minor defects in brain development. We also show that Drosophila Pex7 can function as a bona fide PTS2 receptor because it can rescue targeting of the PTS2-containing protein Thiolase to peroxisomes in $P E X 7$ mutant human fibroblasts.

\section{RESULTS AND DISCUSSION}

\section{Drosophila Pex5 is required for development}

The Pex $5^{M I 06050}$ mutation was caused by a MiMIC insertion disrupting the coding region (Venken et al., 2011). Pex5 is on the $\mathrm{X}$ chromosome and Pex $5^{M I 06050}$ mutants were lethal when homozygous or as hemizygous males with only $20 \%$ of embryos hatching (Figure 1A-C). A further $15 \%$ of $P e x 5^{M I 06050} / P \operatorname{ex} 5^{M I 06050}$ mutants died as larvae with only $5 \%$ 
pupating (Figures 1A1-3, C). The $2 \%$ of pupae survived died at eclosion (Figure 1A1-4, 1C). Pex5 $5^{M 106050} / P e x 5^{M 106050}$ embryos had $35 \%$ of Pex 5 mRNA compared to control (Figure 1B). Maternally provided Pex5 mRNA likely caused the phenotypic variability observed. Finally, strains where the Pex $5^{M I 06050}$ MiMIC element was excised precisely were viable supporting that the phenotypes were due to Pex5 disruption.

Human PEX5 mutations cause central nervous system (CNS), peripheral nervous system (PNS) and musculature defects (Braverman et al., 2013; Steinberg et al., 2006). Thus, we assayed CNS and PNS organization in Pex $5^{M I 06050}$ mutant embryos compared to

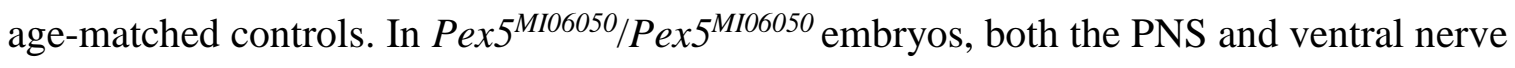
cord (VNC) were disorganized (Figure 2A). PDB patients often show axonal demyelination (Braverman et al., 2013) and while Drosophila neurons are unmyelinated, wrapping glia play an analogous role (Freeman and Doherty, 2006; Matzat et al., 2015). Glial cells were disorganized in $P e x 5^{M I 06050} / P e x 5^{M I 06050}$ embryos compared to controls (Figure 2A). Finally, the developing longitudinal and oblique musculature in late-stage $P e x 5^{M 106050} / P e x 5^{M 106050}$ embryos was also disorganized (Figure 2B).

\section{Drosophila Pex5 is required for peroxisome biogenesis}

To determine if the Pex5 $5^{M I 06050}$ mutation affects PTS1-mediated peroxisome import we analyzed the localization of PTS1/SKL containing proteins in third instar larvae midgut cells (Szilard et al., 1995). A punctate signal, corresponding to peroxisomes with active PTS1 import, was present only in controls. Large SKL-positive aggregates were observed in $P e x 5^{M 106050} / P e x 5^{M I 06005}$ midgut cells indicating lack of PTS1 import (Figure 2C). To examine the systemic effect of $P e x 5^{M I 06050}$ mutation on peroxisome function, we profiled 
the spectrum of fatty acids. Pex $5^{M I 06050} / P e x 5^{M I 06050}$ embryos accumulate VLCFAs $\left(\mathrm{C}_{22}\right.$ and $\mathrm{C}_{24}$ ) and relatively lower levels of $\mathrm{C}_{14}, \mathrm{C}_{16}, \mathrm{C}_{18}$ and $\mathrm{C}_{20}$ compared to controls (Figure 2D).

\section{Drosophila Pex7 is required for neuronal development}

$P e x 7^{M I 4471}$ is caused by MiMIC insertion into the Pex7 coding region (Venken et al., 2011). Unlike $P e x 5^{M I 06050}, P e x 7^{M I 4471} / P e x 7^{M I 4471}$ mutants were viable with only $5 \%$ arresting before pupal stage. Arrested pupae were the same size as control but developmental abnormalities were observed (Figure 1A1, 2, 5). QRTPCR analysis showed $P e x 7^{M I 4471} / P e x 7^{M I 4471}$ embryos had only $10 \%$ Pex7 mRNA relative to controls (Figure 1D). As a symptom of PEX7-linked RDCP is defects neurogenesis (Braverman et al., 2013; Steinberg et al., 2006), we analyzed the brain morphology of $P e x 7^{M I 4471} / P e x 7^{M I 4471}$ third instar larvae. Compared to wild type, $P e x 7^{M I 4471} / P e x 7^{M I 4471}$ larvae were larger (Figure S1A), but their brain volume was smaller (Figure 3A). Although $P e x 7^{M I 4471} / P e x 7^{M I 4471}$ animals were slightly larger than control at the same stage but the mutation did not appear to affect the developmental timing as most of the animals reached the adult stage at the same time as control animals (Figure 1A1,2,5). This phenotype unusual in that small brain / enlarged body size is usually associated with developmental arrest (Colombani et al., 2005; Mirth et al., 2005).

Reduced brain size could be due either to reduced proliferation or excess cell death (apoptosis) (Shklyar et al., 2014). The number of phospho-Ser10-histone 3 (PH3) marked mitotic cells (Wei et al.; 1999) was similar in $P e x 7^{M I 4471} / P e x 7^{M I 4471}$ brains and controls (Figure S1B). Pex $7^{M I 4471} / P e x 7^{M I 4471}$ brain extracts had elevated Active Caspase3 (CM1) levels compared to control (Figure 3B). Also, there were more CM1 positive cells within developing Pex $7^{M I 4471} / P e x 7^{M I 4471}$ brains compared to controls (Figure 3A). Accumulation 
of TUNEL positive cells in the developing brain was also seen in $P e x 7^{M I 4471} / P e x 7^{M I 4471}$ and $P e x 5^{M I 06050} / P e x 5^{M I 06050}$ embryos (Figure 3D, E).

Despite having altered brain morphology, $P$ ex $7^{M I 4471} / P e x 7^{M I 4471}$ mutants are viable. Thus, we functionally assayed neural and muscular function by analyzing the ability of adult flies to exhibit a negative geotaxis response (Madabattula et al., 2015). This climbing assay is used commonly to assay the effects of CNS neurodegeneration in flies (Feany and Bender, 2000). Control flies were more successful in the climbing assay that $P e x 7^{M I 4471} / P e x 7^{M I 4471}$ flies (Figure S1B). Notably, even at the end of the assay (120sec), many Pex $7^{M I 4471} / P e x 7^{M I 4471}$ flies had not completed the task (Figure 3C, S1B).

\section{Drosophila Pex7 has a role in peroxisome fatty acid processing}

Lack of Drosophila PTS2 import calls into question if $P$ ex $7^{M I 4471} / P e x 7^{M I 4471}$ associated defects are linked to peroxisome dysfunction. Non-esterified fatty acids (NEFAs) accumulate in flies with impaired peroxisomes (Bulow et al., 2018). Thus, we measured the relative concentration of circulating NEFAs and observed accumulation in Pex $7^{M I 4471} / P e x 7^{M I 4471}$ larvae compared to control (Figure S1D).

\section{Drosophila Pex7 can functionally substitute for human PEX7}

In human cells, Thiolase is targeted to peroxisomes via PTS2/PEX7 (Braverman et al., 1997). To determine if Drosophila Pex7 retained a similar functional activity, we assayed Thiolase import in human fibroblasts from a RCDP patient with a mutation in PEX7 (Braverman et al., 1997; Purdue et al., 1997). Transfection with a human PEX7 cDNA restored Thiolase import to peroxisomes (Figure 4, S3). Transfection with a Drosophila Pex7 cDNA also rescued Thiolase import indicating Drosophila Pex7 is competent to mediate PTS2 import (Figure 4, S3). 


\section{The role of Drosophila Pex7 is divergent}

Given the previously observed localization of Pex7 to peroxisomes, and the effect on peroxisome size (Baron et al., 2016; Faust et al., 2012; Mast et al., 2011), and effects on lipid processing and brain development we observe in $P e x 7^{M I 4471} / P e x 7^{M I 4471}$ mutants, Pex 7 clearly has a role in peroxisome biogenesis or function. The lack of a canonical PTS2 trafficking pathway in flies, calls into question the mode of action. Drosophila Pex7 homologues of known yeast and human PTS2 targeted proteins have a PTS1 signal (Baron et al., 2016; Faust et al., 2012). It is likely that the canonical PTS2 pathway is not active in Drosophila, as S2 cells cannot import a canonical PTS2-mCherry reporter into peroxisomes while mammalian cells can (Faust et al., 2012). On the other hand, comparison of the amino acid sequence of Drosophila melanogaster Pex7 to Saccharomyces cerevisiae, Arabidopsis thaliana, Danio rerio and Homo sapiens homologs (Figure S2) suggests conservation. Caenorhabditis elegans does not have a PTS2 pathway but does not have a Pex7 homologue either (Motley et al., 2000). It is possible Drosophila has divergent PTS2 signal. Thus, to determine Drosophila does have a divergent PTS2 signal or Pex7 plays a PTS2-independent peroxisomal function, additional studies are needed.

\section{MATERIALS AND METHODS}

\section{Cell culture}

Human fibroblasts were cultured in Dulbecco's modified Eagle's medium (ThermoFisher) supplemented with $10 \%$ (FBS), 50U penicillin/ml and 50 $\mu \mathrm{g}$ streptomycin sulfate $/ \mathrm{ml}$.

\section{Fly husbandry, egg collection and survival assays}


$y^{l} M i\left\{y^{+m D i n t 2}=\right.$ MIC $\left.\} P e x 5^{M I 06050} w^{*} / F M 7 h\right)$ and $y^{l} w^{*} ; M i\left\{y^{+m D i n t 2}=M I C\right\} P e x 7^{M I 14471}$ mutant lines and $\mathrm{FM} 7(\mathrm{GFP}) \mathrm{Df}(1) \mathrm{JA} 27 / F M 7 c, \quad \mathrm{P}\left\{w^{+\mathrm{mC}}=\mathrm{GAL} 4-K r . \mathrm{C}\right\} \mathrm{DC} 1, \quad \mathrm{P}\left\{w^{+\mathrm{mC}}=\mathrm{UAS}-\right.$ GFP.S65T $\}$ DC5, $s n^{+}$strains were obtained from Bloomington Drosophila Stock Center (BDSC). $w^{1118}$ was used as a control in all experiments. Drosophila were maintained at $25^{\circ} \mathrm{C}$ on standard BDSC cornmeal medium. Pex $5^{M I 06050}$ mutants balanced over FM7(GFP) were allowed to lay eggs on apple juice agar plates for two days. On the third day, embryos were collected every $2 \mathrm{~h}$. GFP-negative embryos were incubated on apple juice agar plates at $25^{\circ} \mathrm{C}$. After $24 \mathrm{~h}$ hatched larvae were transferred to standard cornmeal medium and surviving animals were counted at the same time each day.

\section{Geotaxis (climbing) assay}

This assay was performed as described previously (Madabattula et al., 2015) using 20 flies (7 days old) and a 250mL glass graduated cylinder (ThermoFisher), sealed with wax film to prevent escape. Assays were conducted in ambient light at $22^{\circ} \mathrm{C}$ and performed at the same time each day.

\section{Lipid analysis}

One thousand first instar (L1) larvae (equivalent to $1 \mathrm{mg}$ of protein extract) were homogenized in $1 \mathrm{ml}$ PBS buffer and sonicated for $5 \mathrm{~min}$ (BioRuptor) at low power. Lipids were extracted using chloroform:MeOH, 2:1 as described previously (Folch et al., 1957). $5 \mu \mathrm{g}$ of $\mathrm{C} 17$ dissolved in chloroform was used as an internal control. Isolates were centrifuged at $3400 \mathrm{~g}$ and the chloroform phase containing the lipid fraction passed through a sodium sulfate column (GE Bioscience). The eluate was dried under inert gas $\left(\mathrm{N}_{2}\right)$ and resuspended in $100 \mu 1 \mu \mathrm{l}$ of HPLC-grade hexane. $10 \mu 1$ was injected into an Agilent 6890 Gas Chromatograph with Flame-Ionization Detector. VLCFA concentration was 
normalized to the relative amount of protein determined using a Qubit II fluorimeter (ThermoFisher). Non-esterified fatty acids were analysed as per (Bulow et al., 2018).

\section{QRTPCR analysis}

Samples were rinsed twice with PBS, and total RNA extracted using the RNeasy-Micro Kit (Qiagen). 0.5-1 $\mu$ g of RNA was reverse-transcribed using an iScript cDNA Synthesis kit (Biorad), QPCR was performed (Realplex, Eppendorf) using KAPASYBR Green PCR master mix (KAPA Biosystems). Samples were normalized to RpL23 based on the $\Delta \Delta \mathrm{CT}$ method. A Student's t-test was used to calculate significance of differences in gene expression between averaged sample pairs. QRTCPR primer sequences used were:

RpL23, 5'-GACAACACCGGAGCCAAGAACC, 5'-

\section{GTTTGCGCTGCCGAATAACCAC}

Pex5, 5'-AAATGCGAAGACATGGAACC, 5'-TGTAACGCACACGGATGAAG

Pex7, 5'-TCGAAATAGCCAGGCCATCAAG, 5'AAGGAACCGAAGACAAGGACTC

All QRTPCR data shown here are based on 3 biological samples each tested in triplicate.

\section{Protein analysis}

$50 \mu 1$ of cold Ephrussi-Beadle Ringer's solution supplemented with 10mM EDTA, 10mM

DTT, 1x Complete protease inhibitor and 1x PhosStop phosphatase inhibitor (Roche) was added to $3 \times 10^{6}$ pelleted cells. $25 \mu 1$ of $70^{\circ} \mathrm{C} 3 \mathrm{X}$ SDS-PAGE Buffer (Biorad) containing $10 \mathrm{mM}$ DTT was added to the homogenate and incubated at $100^{\circ} \mathrm{C}$ for $10 \mathrm{~min}$. Samples were resolved by SDS-PAGE on $10 \%$ acrylamide gels and transferred onto nitrocellulose membranes (BioRad). Membranes were blocked in 5\% skim milk powder in TBSTw (Trisbuffered saline (150mM NaCl, 20mM Tris $\mathrm{pH} 7.5,0.05 \%$ Tween-20) for $1 \mathrm{~h}$ and incubated for $16 \mathrm{~h}$ with primary antibody in TBSTw. After washing three times 5min with TBSTw, 
membranes were incubated with HRP-conjugated secondary antibody (1:10,000 BioRad) for $1 \mathrm{~h}$ at $24^{\circ} \mathrm{C}$. Membranes were washed as above and HRP detected by enhanced chemiluminescence (Amersham). Primary antibodies were: rabbit anti-Thiolase (Bodnar and Rachubinski, 1990) mouse anti-Tubulin (Sigma-Aldrich 1:1000).

\section{Human PEX7 and Drosophila Pex7 cDNA cloning and transfection}

The open reading frame of human PEX7 cDNA (Braverman et al., 1997) was cloned into pENTR/D (ThermoFisher) using hPex7-Forward (5'CACCATGAGTGCGGTGTGCGGTGG) and hPex7-Reverse (5'GGTCAAGCAGGAATAGTAAGACAAG) primers. The Drosophila Pex7 cDNA clone was described previously (Baron et al., 2016). Both were transferred into pT-Rex-DEST30 vector using LR Clonase (ThermoFisher). These were transiently transfected into immortalized human fibroblasts using the Amaxa Human Dermal Fibroblast Nucleofector Kit (Lonza).

\section{Microscopy}

Human fibroblasts were fixed for $30 \mathrm{~min}$ in $4 \%$ paraformaldehyde in phosphate buffered saline $(\mathrm{PBS})$, rinsed twice in PBST (PBS+0.1\% TritonX-100) and blocked for $1 \mathrm{~h}$ in 5\% NGS (Sigma) before incubation for $16 \mathrm{~h}$ at $4^{\circ} \mathrm{C}$ with primary antibodies. Following 4 washes in PBST, each were incubated in secondary antibody for $16 \mathrm{~h}$ at $4^{\circ} \mathrm{C}$. After 4 washes in PBST, coverslips were mounted using Prolong-Gold (ThermoFisher). Images were captured using a C9100 camera (Hamamatsu) at 130 $\mu \mathrm{m}$ vertical spacing using a 100X oil immersion objective $(\mathrm{NA}=1.4)$ on a Zeiss AxioObserverM1 microscope coupled to an ERS spinning disk confocal (PerkinElmer). Primary antibodies included: anti-mouse PMP70 (Sigma-Aldrich) (Imanaka et al., 2000); Activated Caspase3 (559565, BD Pharmagen), 
anti-phosphohistone H3 (Upstate Biotechnology), rabbit anti-SKL (Szilard et al., 1995) and anti-rat Thiolase (Bodnar and Rachubinski, 1990). Secondary antibodies were: AlexaFluor568 donkey anti-mouse, AlexaFluor488 donkey anti-rat or AlexaFluor647 donkey anti-rabbit (Abcam, 1:1000).

Embryos were collected every $16 \mathrm{~h}$ at $18^{\circ} \mathrm{C}$ and processed as reported previously (Parsons and Foley, 2013). Antibodies to Futch (22C10) raised by Seymour Benzer, California Institute of Technology, Even-skipped (2B8) and Repo (8D12) raised by Corey Goodman, University of California, were from the Developmental Studies Hybridoma Bank. Anti-Myosin II was from Abcam (ab51098). All primary antibodies were diluted 1:20, and AlexaFluor568 donkey anti-mouse was the secondary antibody (1:1000, Abcam). Embryo TUNEL staining was performed as described previously (Parsons and Foley, 2013). 


\section{REFERENCES}

Baron, M.N., Klinger, C.M., Rachubinski, R.A., and Simmonds, A.J. (2016). A Systematic

Cell-Based Analysis of Localization of Predicted Drosophila Peroxisomal Proteins. Traffic 17, 536-553.

Baroy, T., Koster, J., Stromme, P., Ebberink, M.S., Misceo, D., Ferdinandusse, S., Holmgren, A., Hughes, T., Merckoll, E., Westvik, J., et al. (2015). A novel type of rhizomelic chondrodysplasia punctata, RCDP5, is caused by loss of the PEX5 long isoform. Hum Mol Genet 24, 5845-5854.

Beard, M.E., and Holtzman, E. (1987). Peroxisomes in wild-type and rosy mutant Drosophila melanogaster. Proc Natl Acad Sci U S A 84, 7433-7437.

Bodnar, A.G., and Rachubinski, R.A. (1990). Cloning and sequence determination of cDNA encoding a second rat liver peroxisomal 3-ketoacyl-CoA thiolase. Gene 91, 193-199.

Bowers, W.E. (1998). Christian de Duve and the discovery of lysosomes and peroxisomes. Trends Cell Biol 8, 330-333.

Braverman, N., Steel, G., Obie, C., Moser, A., Moser, H., Gould, S.J., and Valle, D. (1997). Human PEX7 encodes the peroxisomal PTS2 receptor and is responsible for rhizomelic chondrodysplasia punctata. Nat Genet 15, 369-376.

Braverman, N.E., D'Agostino, M.D., and Maclean, G.E. (2013). Peroxisome biogenesis disorders: Biological, clinical and pathophysiological perspectives. Dev Disabil Res Rev 17, 187-196.

Bulow, M.H., Wingen, C., Senyilmaz, D., Gosejacob, D., Sociale, M., Bauer, R., Schulze, H., Sandhoff, K., Teleman, A.A., Hoch, M., et al. (2018). Unbalanced lipolysis 
results in lipotoxicity and mitochondrial damage in peroxisome-deficient Pex19 mutants. Mol Biol Cell 29, 396-407.

Chen, H., Liu, Z., and Huang, X. (2010). Drosophila models of peroxisomal biogenesis disorder: peroxins are required for spermatogenesis and very-long-chain fatty acid metabolism. Hum Mol Genet 19, 494-505.

Colombani, J., Bianchini, L., Layalle, S., Pondeville, E., Dauphin-Villemant, C., Antoniewski, C., Carre, C., Noselli, S., and Leopold, P. (2005). Antagonistic actions of ecdysone and insulins determine final size in Drosophila. Science 310, 667-670.

Deduve, C. (1965). Functions of Microbodies (Peroxisomes). Journal of Cell Biology 27, A25-\&.

Facciotti, F., Ramanjaneyulu, G.S., Lepore, M., Sansano, S., Cavallari, M., Kistowska, M., Forss-Petter, S., Ni, G., Colone, A., Singhal, A., et al. (2012). Peroxisome-derived lipids are self antigens that stimulate invariant natural killer T cells in the thymus. Nat Immunol 13, 474-480.

Faust, J.E., Manisundaram, A., Ivanova, P.T., Milne, S.B., Summerville, J.B., Brown, H.A., Wangler, M., Stern, M., and McNew, J.A. (2014). Peroxisomes are required for lipid metabolism and muscle function in Drosophila melanogaster. PLoS One 9, e100213.

Faust, J.E., Verma, A., Peng, C., and McNew, J.A. (2012). An inventory of peroxisomal proteins and pathways in Drosophila melanogaster. Traffic 13, 1378-1392.

Feany, M.B., and Bender, W.W. (2000). A Drosophila model of Parkinson's disease. Nature 404, 394-398. 
Folch, J., Lees, M., and Sloane Stanley, G.H. (1957). A simple method for the isolation and purification of total lipides from animal tissues. J Biol Chem 226, 497-509.

Freeman, M.R., and Doherty, J. (2006). Glial cell biology in Drosophila and vertebrates. Trends Neurosci 29, 82-90.

Imanaka, T., Aihara, K., Suzuki, Y., Yokota, S., and Osumi, T. (2000). The 70-kDa peroxisomal membrane protein (PMP70), an ATP-binding cassette transporter. Cell Biochem Biophys 32 Spring, 131-138.

Ito, T., Fujimura, S., Matsufuji, Y., Miyaji, T., Nakagawa, T., and Tomizuka, N. (2007). Molecular characterization of the PEX5 gene encoding peroxisomal targeting signal 1 receptor from the methylotrophic yeast Pichia methanolica. Yeast 24, 589597.

Kanzawa, N., Shimozawa, N., Wanders, R.J., Ikeda, K., Murakami, Y., Waterham, H.R., Mukai, S., Fujita, M., Maeda, Y., Taguchi, R., et al. (2012). Defective lipid remodeling of GPI anchors in peroxisomal disorders, Zellweger syndrome, and rhizomelic chondrodysplasia punctata. J Lipid Res 53, 653-663.

Klein, A.T., Barnett, P., Bottger, G., Konings, D., Tabak, H.F., and Distel, B. (2001). Recognition of peroxisomal targeting signal type 1 by the import receptor Pex $5 p$. J Biol Chem 276, 15034-15041.

Kragler, F., Lametschwandtner, G., Christmann, J., Hartig, A., and Harada, J.J. (1998). Identification and analysis of the plant peroxisomal targeting signal 1 receptor NtPEX5. Proc Natl Acad Sci U S A 95, 13336-13341.

Lazarow, P.B. (2006). The import receptor Pex7p and the PTS2 targeting sequence. Biochim Biophys Acta 1763, 1599-1604. 
Lepore, M., de Lalla, C., Gundimeda, S.R., Gsellinger, H., Consonni, M., Garavaglia, C., Sansano, S., Piccolo, F., Scelfo, A., Haussinger, D., et al. (2014). A novel selflipid antigen targets human T cells against CD1c(+) leukemias. J Exp Med 211, 1363-1377.

Madabattula, S.T., Strautman, J.C., Bysice, A.M., O'Sullivan, J.A., Androschuk, A., Rosenfelt, C., Doucet, K., Rouleau, G., and Bolduc, F. (2015). Quantitative Analysis of Climbing Defects in a Drosophila Model of Neurodegenerative Disorders. J Vis Exp, e52741.

Mast, F.D., Li, J., Virk, M.K., Hughes, S.C., Simmonds, A.J., and Rachubinski, R.A. (2011). A Drosophila model for the Zellweger spectrum of peroxisome biogenesis disorders. Dis Model Mech 4, 659-672.

Matsumura, T., Otera, H., and Fujiki, Y. (2000). Disruption of the interaction of the longer isoform of Pex5p, Pex5pL, with Pex7p abolishes peroxisome targeting signal type 2 protein import in mammals. Study with a novel Pex5-impaired Chinese hamster ovary cell mutant. J Biol Chem 275, 21715-21721.

Matzat, T., Sieglitz, F., Kottmeier, R., Babatz, F., Engelen, D., and Klambt, C. (2015). Axonal wrapping in the Drosophila PNS is controlled by glia-derived neuregulin homolog Vein. Development 142, 1336-1345.

McCollum, D., Monosov, E., and Subramani, S. (1993). The pas8 mutant of Pichia pastoris exhibits the peroxisomal protein import deficiencies of Zellweger syndrome cells-the PAS8 protein binds to the $\mathrm{COOH}$-terminal tripeptide peroxisomal targeting signal, and is a member of the TPR protein family. J Cell Biol 121, 761-774. 
Mirth, C., Truman, J.W., and Riddiford, L.M. (2005). The role of the prothoracic gland in determining critical weight for metamorphosis in Drosophila melanogaster. Curr Biol 15, 1796-1807.

Motley, A.M., Hettema, E.H., Ketting, R., Plasterk, R., and Tabak, H.F. (2000). Caenorhabditis elegans has a single pathway to target matrix proteins to peroxisomes. EMBO Rep 1, 40-46.

Nakayama, M., Sato, H., Okuda, T., Fujisawa, N., Kono, N., Arai, H., Suzuki, E., Umeda, M., Ishikawa, H.O., and Matsuno, K. (2011). Drosophila carrying pex3 or pex16 mutations are models of Zellweger syndrome that reflect its symptoms associated with the absence of peroxisomes. PLoS One 6, e22984.

Nguyen, S.D., Baes, M., and Van Veldhoven, P.P. (2008). Degradation of very long chain dicarboxylic polyunsaturated fatty acids in mouse hepatocytes, a peroxisomal process. Biochim Biophys Acta 1781, 400-405.

Parsons, B., and Foley, E. (2013). The Drosophila platelet-derived growth factor and vascular endothelial growth factor-receptor related (Pvr) protein ligands Pvf2 and Pvf3 control hemocyte viability and invasive migration. J Biol Chem 288, 2017320183.

Platta, H.W., and Erdmann, R. (2007). Peroxisomal dynamics. Trends Cell Biol 17, 474484.

Purdue, P.E., Yang, X., and Lazarow, P.B. (1998). Pex18p and Pex21p, a novel pair of related peroxins essential for peroxisomal targeting by the PTS2 pathway. J Cell Biol 143, 1859-1869. 
Purdue, P.E., Zhang, J.W., Skoneczny, M., and Lazarow, P.B. (1997). Rhizomelic chondrodysplasia punctata is caused by deficiency of human PEX7, a homologue of the yeast PTS2 receptor. Nat Genet 15, 381-384.

Rehling, P., Marzioch, M., Niesen, F., Wittke, E., Veenhuis, M., and Kunau, W.H. (1996). The import receptor for the peroxisomal targeting signal 2 (PTS2) in Saccharomyces cerevisiae is encoded by the PAS7 gene. EMBO J 15, 2901-2913.

Schrader, M., and Fahimi, H.D. (2006). Peroxisomes and oxidative stress. Biochim Biophys Acta 1763, 1755-1766.

Shimozawa, N., Zhang, Z., Suzuki, Y., Imamura, A., Tsukamoto, T., Osumi, T., Fujiki, Y., Orii, T., Barth, P.G., Wanders, R.J., et al. (1999). Functional heterogeneity of Cterminal peroxisome targeting signal 1 in PEX5-defective patients. Biochem Biophys Res Commun 262, 504-508.

Shklyar, B., Sellman, Y., Shklover, J., Mishnaevski, K., Levy-Adam, F., and Kurant, E. (2014). Developmental regulation of glial cell phagocytic function during Drosophila embryogenesis. Dev Biol 393, 255-269.

Smith, J.J., and Aitchison, J.D. (2013). Peroxisomes take shape. Nat Rev Mol Cell Biol 14, 803-817.

Steinberg, S.J., Dodt, G., Raymond, G.V., Braverman, N.E., Moser, A.B., and Moser, H.W. (2006). Peroxisome biogenesis disorders. Biochim Biophys Acta 1763, 1733-1748.

Szilard, R.K., Titorenko, V.I., Veenhuis, M., and Rachubinski, R.A. (1995). Pay32p of the yeast Yarrowia lipolytica is an intraperoxisomal component of the matrix protein translocation machinery. J Cell Biol 131, 1453-1469. 
Venken, K.J., Schulze, K.L., Haelterman, N.A., Pan, H., He, Y., Evans-Holm, M., Carlson, J.W., Levis, R.W., Spradling, A.C., Hoskins, R.A., et al. (2011). MiMIC: a highly versatile transposon insertion resource for engineering Drosophila melanogaster genes. Nat Methods 8, 737-743.

Wanders, R.J., and Waterham, H.R. (2006). Biochemistry of mammalian peroxisomes revisited. Annu Rev Biochem 75, 295-332.

Woodward, A.W., and Bartel, B. (2005). The Arabidopsis peroxisomal targeting signal type 2 receptor PEX7 is necessary for peroxisome function and dependent on PEX5. Mol Biol Cell 16, 573-583. 


\section{FIGURE LEGENDS}

Fig. 1. Pex5 and Pex7 mutants present developmental defects. (A) 1. Control pupa 7 days after egg laying (AEL). 2. Control adults eclosed at day 9 AEL. 3. Most $P e x 5^{M 106050} / P e x 5^{M I 06050}$ mutants arrest at pseudo-pupa stage (day 11 AEL) 4. Some Pex5 $5^{M 106050} / P_{e x 5^{M I 06050}}$ mutants die during eclosion (day 10 AEL). 5. Some $P e x 7^{M I 4471} / P \operatorname{ex} 7^{M I 4471}$ mutants arrest at pupa stage (day 11 AEL). Scale bar=1mm. (B) QRTPCR confirms reduction in the amount of Pex5 mRNA in Pex5 $5^{M 106050} / P \operatorname{ex} 5^{M I 06050}$ embryos, relative to controls. Values are averages of 4 independent experiments \pm SD. Significance was determined using Student's t-test; *** $\mathrm{p}<0.001$. (C) Most $P e x 5^{M 106050} / P e x 5^{M I 06050}$ mutants die at embryo stage and none eclose as adults. Values are averages of 4 independent experiments \pm SD. N=200 embryos were analyzed for each genotype. Significance was determined using Student's $t$-test; *** $\mathrm{p}<0.001$. (D) QRTPCR confirms reduction of Pex7 mRNA in $P e x 7^{M I 4471} / P e x 7^{M I 4471}$ embryos, relative to control. Values are averages of 4 independent experiments \pm SD. Significance was determined using Student's $t$-test; *** $\mathrm{p}<0.001$.

Fig. 2. The Pex $5^{M 106050}$ mutation affects NS, PNS and muscle development. (A) The repeated segmental pattern of neuron of the CNS and PNS (marked by anti-Futsch), CNS axons (marked by anti-Even-skipped) and glia cells (except midline glia, marked by antiRepo) in control embryos (stage 15). This pattern is severely disrupted in $P e x 5^{M 106050} / P e x 5^{M I 06050}$ embryos. Scale bar=10 $\mu \mathrm{m}$. (B) The repeated segmental pattern of developing muscles marked by Anti-Myosin II in control embryos is disrupted in

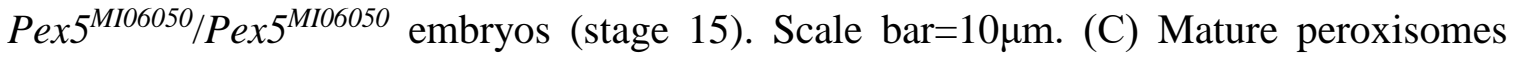

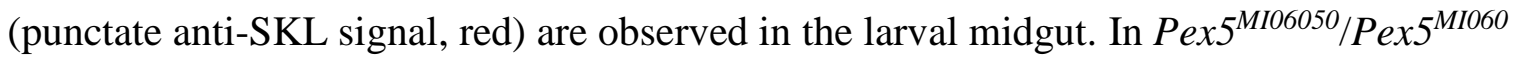


mutants, diffuse SKL aggregates indicate PTS1 import was impaired. DAPI labelled nuclei are in grey. The boxed region in the top panel is shown magnified in the lower panel. Scale bar=10 $\mu \mathrm{m}(\mathrm{D}) P e x 5^{M I 06050} / P e x 5^{M I 060}$ mutants have lower long chain fatty acid levels $\left(\mathrm{C}_{14}\right.$, $\mathrm{C}_{16}$ and $\left.\mathrm{C}_{18}\right)$ and accumulate VLCFAs (C20, C22 and C24) compared to controls. Values are averages of 4 independent experiments \pm SD. N=1000 larvae per sample per each genotype were used in each replicate (4000 total). Significance was determined using Student's $t$-test; *** $\mathrm{p}<0.001 ; * * \mathrm{p}<0.01$

Fig. 3. Pex 7 mutation causes defects in CNS development. (A) $P e x 7^{M I 4471} / P e x 7^{M I 4471}$ larvae that arrest between second and third instar had smaller brains than control. The number of apoptotic cells (marked by activated Caspase3, CM1) was higher in Pex $7^{M I 4471} /$ Pex $7^{\text {MI447 }}$ brains. Scale bar=10 $\mu \mathrm{m}$. (B) Total CM1 levels were higher $P e x 7^{M I 4471} / P e x 7^{M I 447}$ second and third instar larval brains. Values represent averages of 4 independent experiments \pm SD. Significance was determined using Student's $t$-test; *** $\mathrm{p}$ $<0.001$. (C) $P e x 7^{M I 4471} / P e x 7^{M I 4471}$ show reduced performance in a climbing assay, testing coordinated locomotion, than control. Values represent averages of 12 independent experiments $\pm \mathrm{SD}$. Significance was determined using Student's $t$-test; * $\mathrm{p}<0.05$. (D) TUNEL positive cells were detected around the embryonic CNS in Pex $7^{M 14471} /$ Pex $7^{M I 447}$ embryos compared to control. (E) $P e x 5^{M 106050} / P e x 5^{M I 06050}$ embryos also had elevated numbers of TUNEL postive cells in the CNS. Images are representative of 4 independent experiments. $\mathrm{N}=20$ per experiment/genotype. Scale bar $=10 \mu \mathrm{m}$.

Fig. 4. Drosophila Pex7 can facilitate PTS2 import in human cells. In wild type human fibroblasts, anti-Thiolase marks punctate cytoplasmic spots co-localizing with a peroxisome membrane marker antiPMP70. PEX7 mutant fibroblasts $\left(P E X 7^{\text {null }}\right)$ do not have 
punctate Thiolase signal indicating lack of import but PMP70 puncta remain, indicating peroxisomes are present. Transfection of $P E X 7^{\text {null }}$ cells with $P E X 7 c D N A$ restores Thiolase import to peroxisomes. Expression of a Drosophila Pex7 cDNA in PEX7 null human fibroblasts also restored Thiolase import to peroxisomes. Scale bar $=10 \mu \mathrm{m}$.

\section{SUPPLEMENTARY FIGURE LEGENDS}

Fig. S1. Pex7 mutant show neural defects. (A) Age matched $P e x 7^{M I 4471} / P \operatorname{ex} 7^{M I 4471}$ homozygous larvae are larger than control larvae at the L2-L3 molt. (B) Brains from

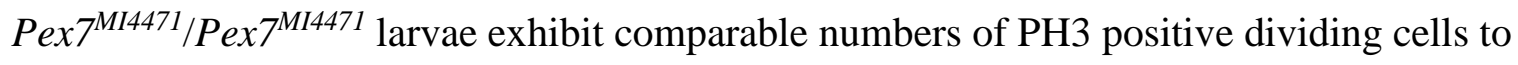
control flies. Scale bar $=1 \mu \mathrm{m}(\mathrm{C})$ The percentage of $P e x 7^{M I 4471} / P e x 7^{M I 4471}$ flies having passed the threshold line in the climbing assay represented every $10 \mathrm{sec}$ is less than control. Significance was determined using Kolmogorov-Smirnov test to compare the distributions of the mutant group to the control. $\mathrm{N}=12$ per time point; $* \mathrm{p}<0.05$. (D) Amounts of NEFAs in larvae from control and $P e x 7^{M I 4471} / P e x 7^{M I 4471}$ mutant L3 larvae. Values represent averages of 3 independent experiments \pm SD. Significance was determined using Student's t-test; $* \mathrm{p}<0.05$

Fig. S2. Sequence alignment of Pex7 protein homologues. Sequence alignment of human (HsPex7p, CAG46851.1)), zebrafish (DrPex7p, AAI64338.1), plant (AtPex7p, OAP16388.1), yeast (ScPex7p, KZV12380.1) and fruit fly (DmPex7p, NP_001137914.1). Amino acid sequences were aligned with use of the Kalign program (https://www.ebi.ac.uk/Tools/msa/kalign). Residues that are identical (blue) or similar (yellow) to residues in Drosophila Pex7 are shaded. Similarity rules: $G=A=S ; A=V ; V$ $=\mathrm{I}=\mathrm{L}=\mathrm{M} ; \mathrm{I}=\mathrm{L}=\mathrm{M}=\mathrm{F}=\mathrm{Y}=\mathrm{W} ; \mathrm{K}=\mathrm{R}=\mathrm{H} ; \mathrm{D}=\mathrm{E}=\mathrm{Q}=\mathrm{N} ;$ and $\mathrm{S}=\mathrm{T}=\mathrm{Q}=\mathrm{N}$. Dashes represent gaps. Sequence accession numbers are given between brackets. 
A)

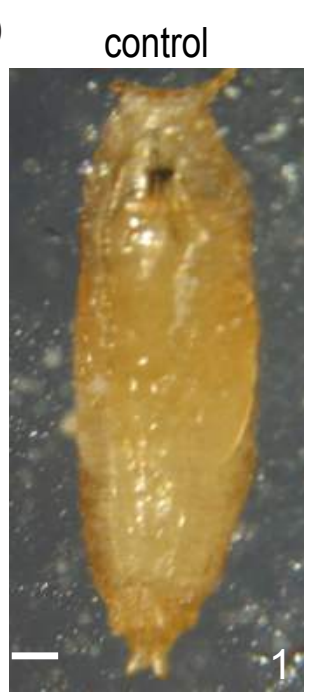

B)

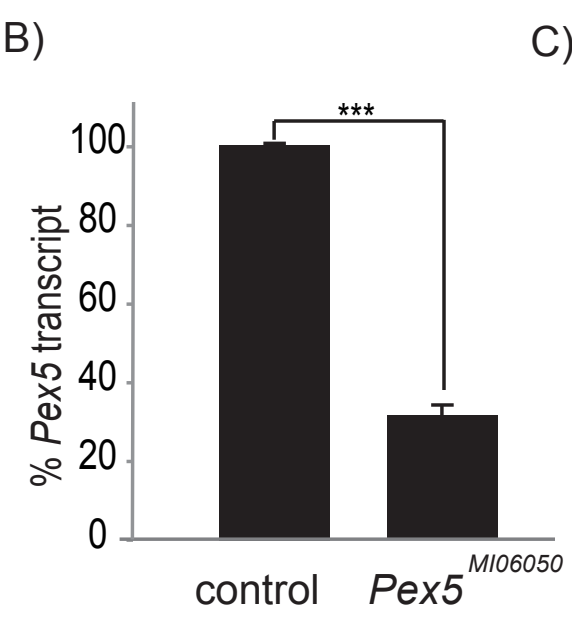

D)
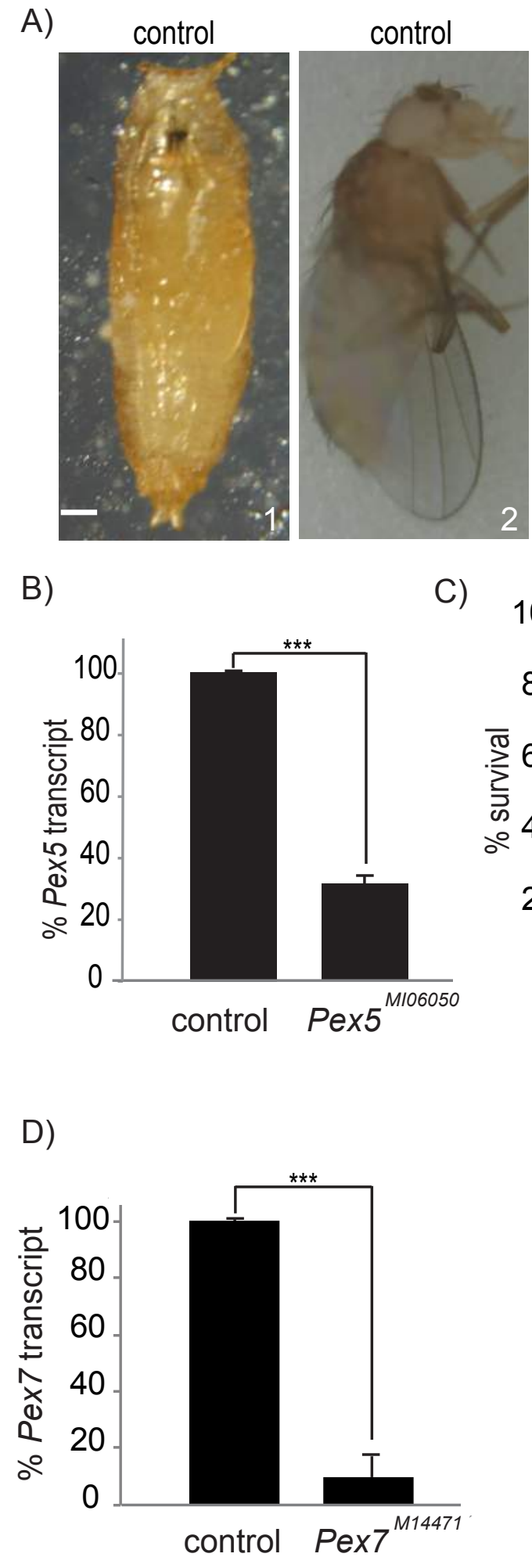
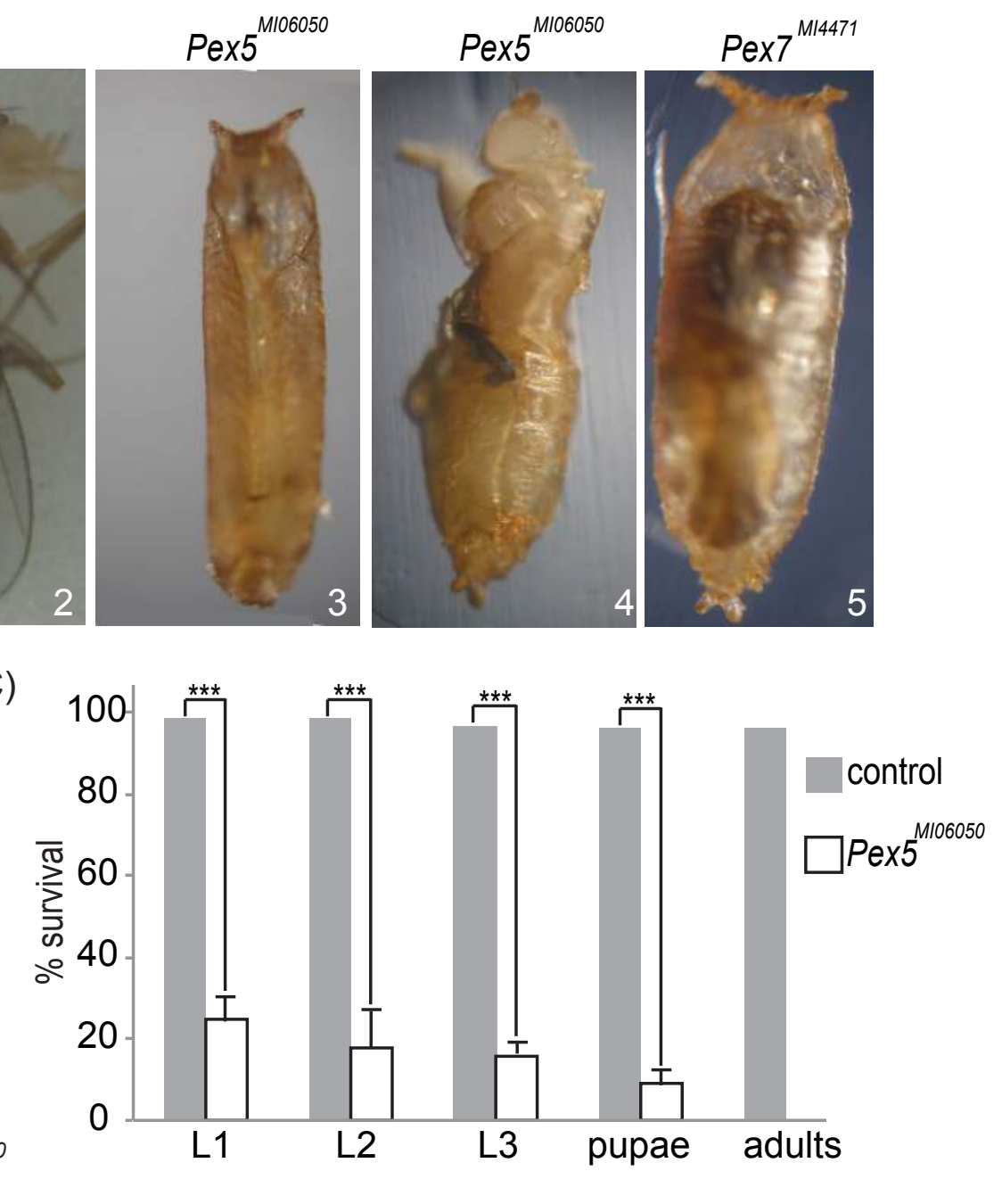
bioRxiv preprint doi: https://doi.org/10.1101/366633; this version posted July 10,2018 . The copyright holder for this preprint (which was not certified by peer review) is the author/funder. All rights reserved. No reuse allowed without permission.
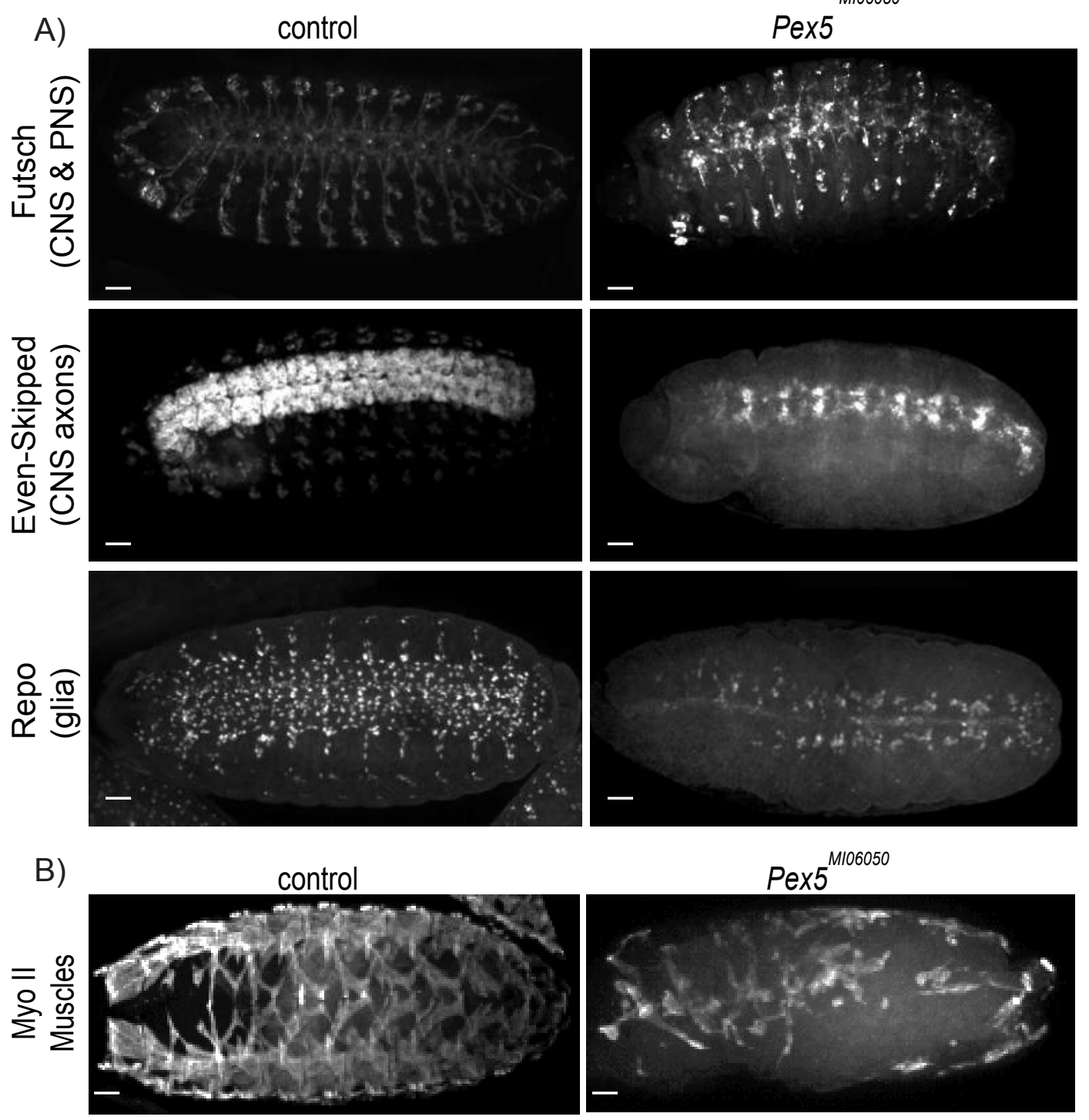

C)

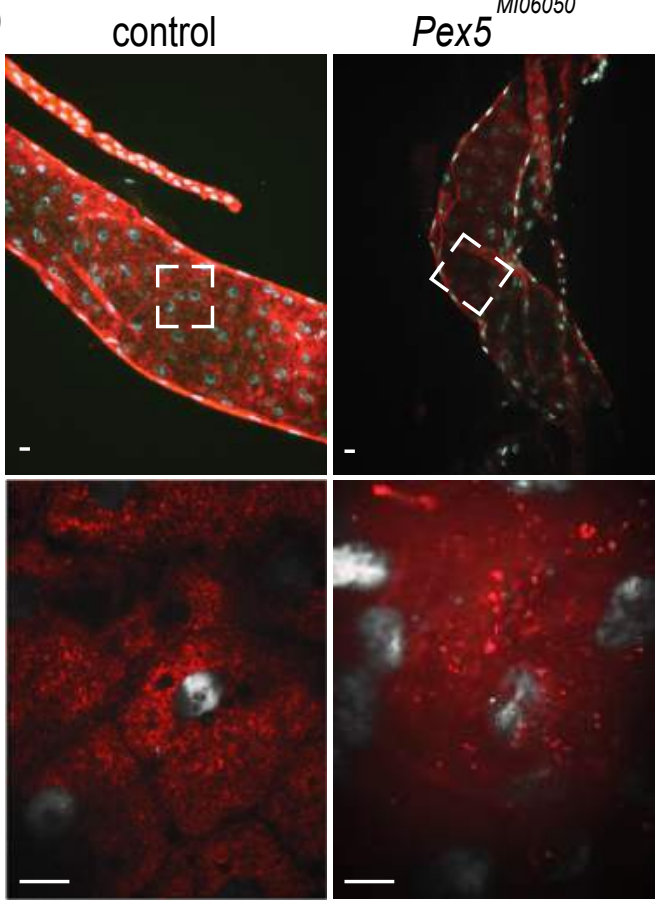

D)

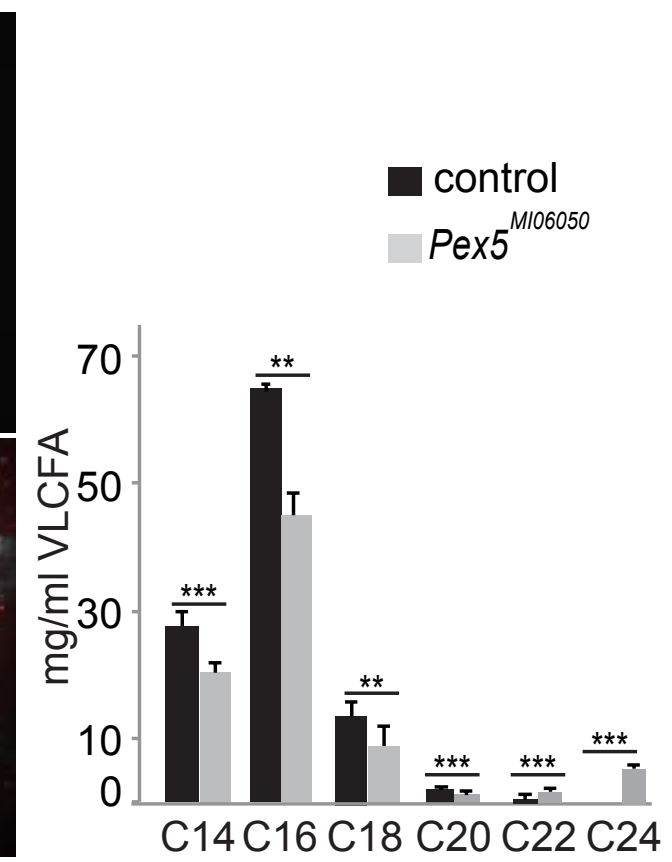


A)
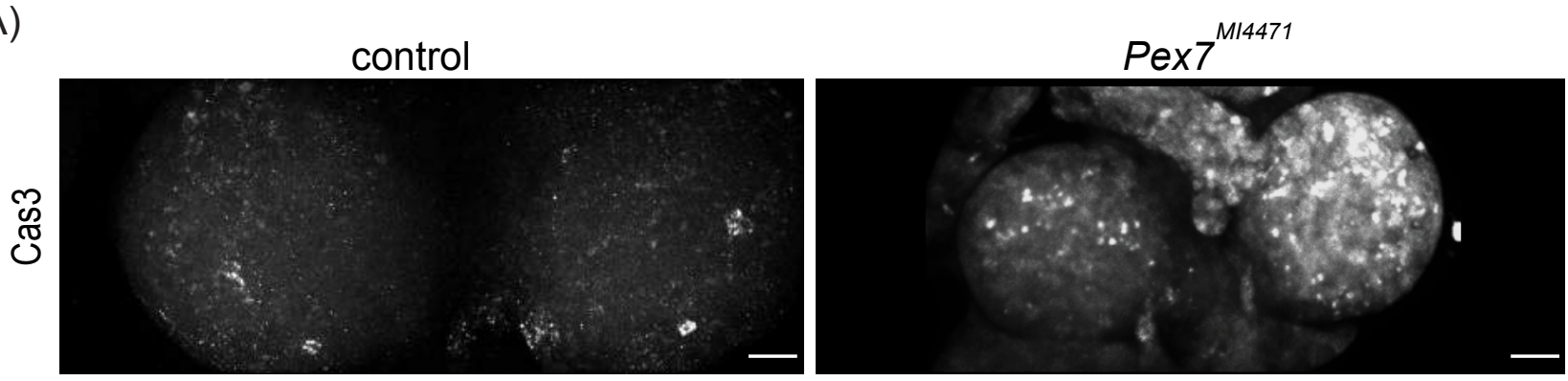

B)
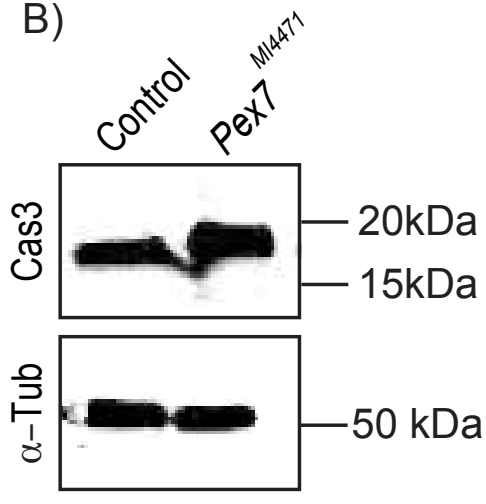

D)

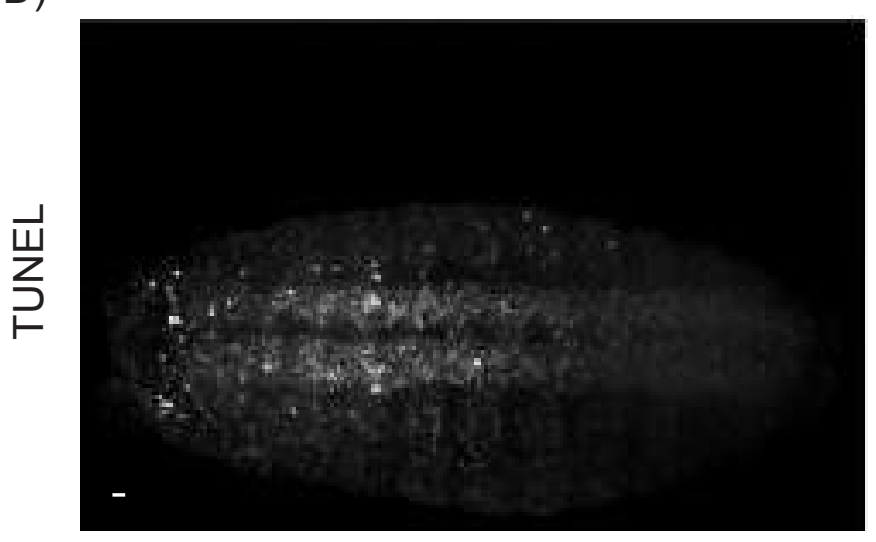

E)

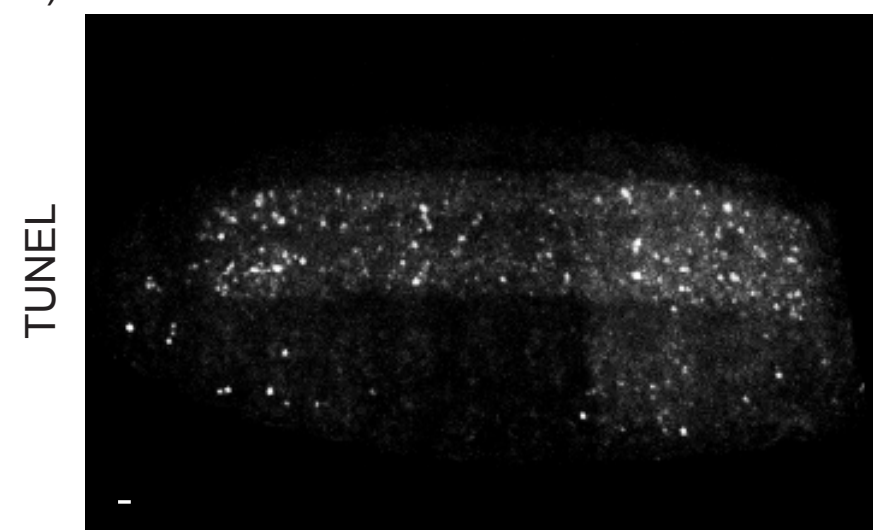

C)

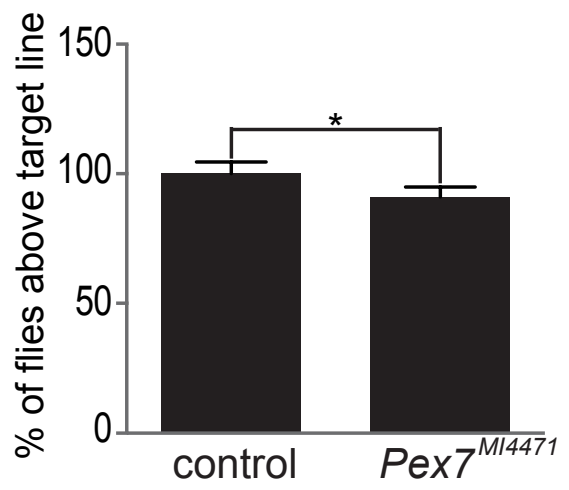

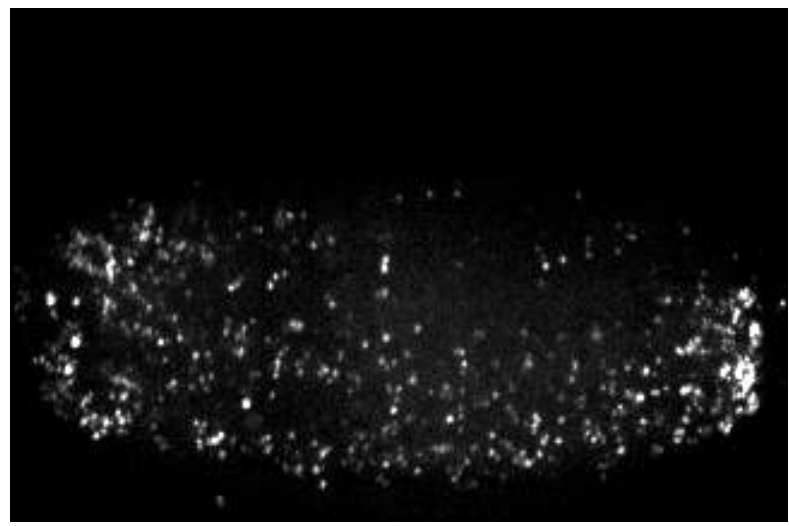

Pex5

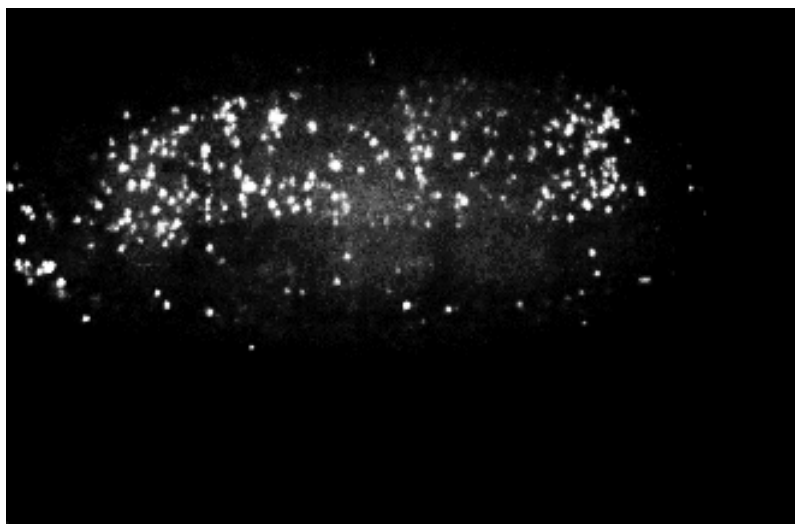


bioRxiv preprint doi: https://doi.org/10.1101/366633; this version posted July 10, 2018. The copyright holder for this preprint (which was not

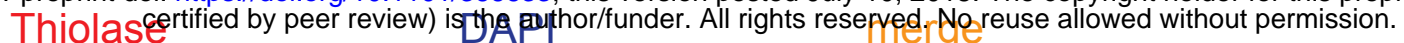

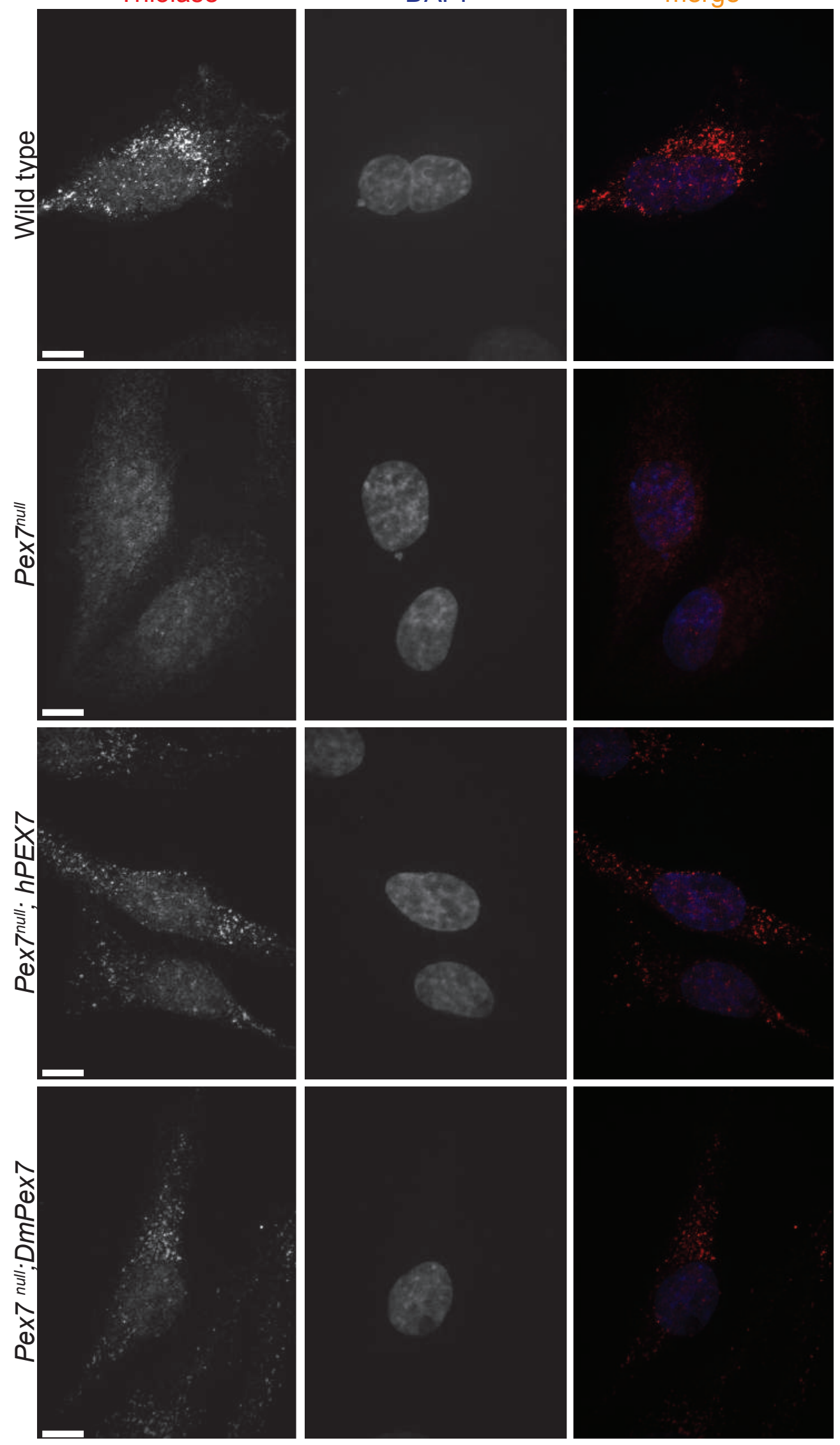

Figure 4

Di Cara et al., 
A)

$$
\text { Control Pext } 7^{\text {M14471 }}
$$

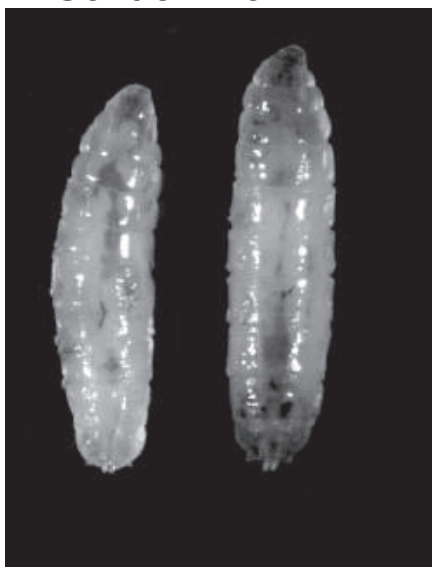

C)

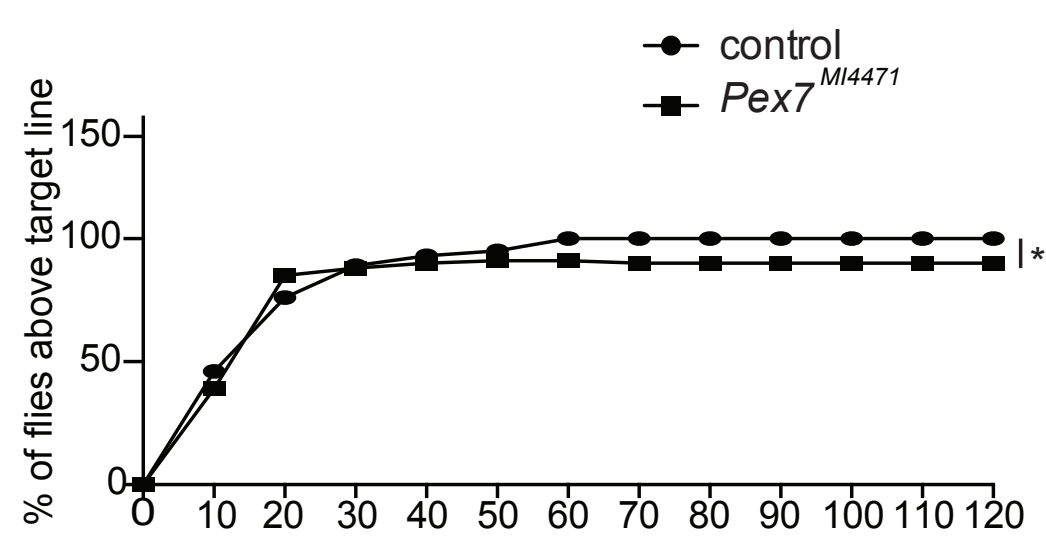

B)

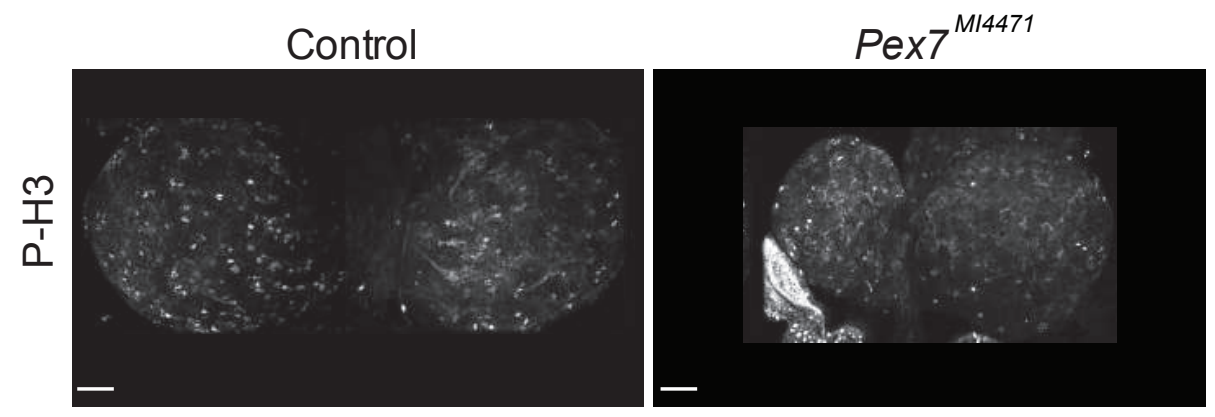

D)

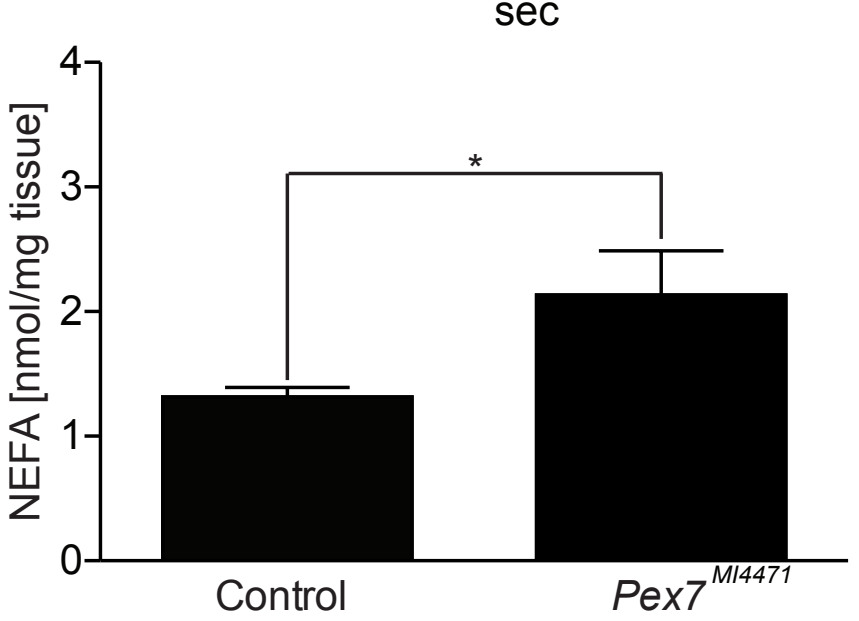


HsPex $7 p$

$\operatorname{DrPex} 7 \mathrm{p}$

AtPex $7 p$

SCPex $7 p$

DmPex7p

1 MSAVCGGAARMLRTPGRHGYAAEFSPYLPGRLACATAQHYGIAGCGTLLILD--PDE---

1 -- - - MKSFKSPGRHGYAVEISPFLPSTMACASSQCYGIAGCGTLFVLE--QRE---

1 -- --MPVFKAP-FNGYSVKFSPFYESRLAVATAQNFGILGNGRIHVLELAPGA---

1 -- - - MLRYHMQGFSGYGVQYSPFFDNRLAVAAGSNFGLVGNGKLFILEI-DRS--

1 MQ------TQTHTTTDRHGYSLRFSPFEANYLLLATSQLYGLAGGGSLFLLE--QNSNTN

HSPex7p 56 ------AGLRLFRSFDWNDGLFDVTWSENNEHVLITCSGDGSLQLW--------DTA--

DrPex7p 48 ------TDVSLVKSFDWNDGLFDVTWSENNEHVLVTGGGDGSLQIW--------DTA--

AtPex7p 49 -..--PGVTESVSYDTADAVYDVCWSESHDSVLIAAIGDGSVKIY---.---DTALP

SCPex7p 49 ------GRIVEVNSFLTQDCLFDLAWNESHENQVLVAQGDGTLRLF--------DTT--

DmPex7p 53 SSSTDGQSLGELCRLEWSDGLFDVAWCPYAADIAATASGDGSLQIWCGLDGESASNQL--

HSPex7p 99 KAAGPLQVYKEHAQEVYSVDWSQTRGEQLVVSGSWDQTVKLWDPTVGKSLCTFR-----DrPex7p 91 NPQGLLQVLKGHTQEVYSVDWSQTRAENLLVSGSWDHTAKVWDPVQCQLVNSLQ-----AtPex7p 94 PPSNPIRSFQEHAREVQSVDYNPTRRDSFLTS-SWDDTVKLWAMDRPASVRTFK-----SCPex7p 92 FKEFPIAIFKEHEREVFSCNWNLVNRQNFLSS-SWDGSIKIWSPLRKQSLMTLTPRPLEI DMPex7p 111 TPKQPLICLQEHKNEVYSLDWGEKWNYHTLLSGSWDCTLKLWDCNRQNSITTFV------

HSPex7p 153 -------------GHESIIYSTIWSPHIPGCFASASGDQTLRIWDVK--AAG DrPex7p 145 ------------ GHEGVIYSTIWSPHIPACFASASGDGTLRVWDVK--AGS AtPex7p 147 - - SCPEX7p 151 TKMVDPLNAIILKKKSFTGISKNRNCVYQAQFSPHDQNLVLSCSGNSYASLFDIRLPSGK DmPex7p 165 --------------GHNDLIYGAKFSPLIANLFASVSTDGHLNLWNSLDFAGK

HSPex7p 190 VRIVIPAHQ-AEILSCDWCKYNENLLVTGAVDCSLRGWDLRNVRQPVFEL---------DrPex7p 182 CRLVIPAHK-SEILSCDWCKYDQNVIVTGAVDCSLRVWDLRNIRHPVAQM----.---AtPex7p 184 STMIIPAHD-FEILSCDWNKYDDCILATSSVDKTVKVWDVRSYRVPLAVL--------SCPex7p 211 NQNNFLVHSGLEALTCDFNKYRPYVVATGGVDNAIRIWDIRMLNKNESATIKRTVPGQLH DmPex7p 204 PLMSIEAHA-SEALCCDWSHFDRNVLVTGGSDGLIRGWDLRKMRTHVFEL---------

HSPex7p $239-------$ LGHTYAIRRVKFSPFHASVLASCSYDFTVRFWNFSKPDSLLETVE-----DrPex7p $231------S G H S Y A I R R V K F C P F Y K T V L A S C S Y D F T V R F W D Y S K S Q A L L E T L E-----$ AtPex7p 233 -------NGHGYAVRKVKFSPHRRSLIASCSYDMSVCLWDYMVEDALVGRYD----SCPex7p 271 NSSCINEIPNAHGLAIRKVTWSPHHSNILMSASYDMTCRIWRDLSNDGAKETYKTNSTDA DmPex7p 253 -------YSGEFAVRRLACSPHSAAVLASANYDFTTRIWNLERGESAQEVNA------

HSPex7p 284 -------HHTEFTCGLDFSLQ-SPTQVADCSWDETIKIYDPACLTIPA-DrPex7p $276-------H H S E F V C G L N F N L H-I P N Q V V D C S W D E T V K V F S P S S L A A V---$ AtPex7p $278------$ HHTEFAVGIDMSVL-VEGLMASTGWDELVYVWQQGMDPRAS-ScPex7p 331 TKGSIFNFTQHSEFVFGADWSLWGKPGYVASTAWDGNLFVWNGLG-----DmPex7p 298 -------RHTEFVCGLDWNPH-RTHQLADCGWDSLANVYTPQCLSGDLVV 
bioRxiv preprint doi: https://doi.org/10.1101/366633; this version posted July 10,2018 . The copyright holder for this preprint (which was not certified by peer review) is the author/funder. All rights reserved. No reuse allowed without permission.

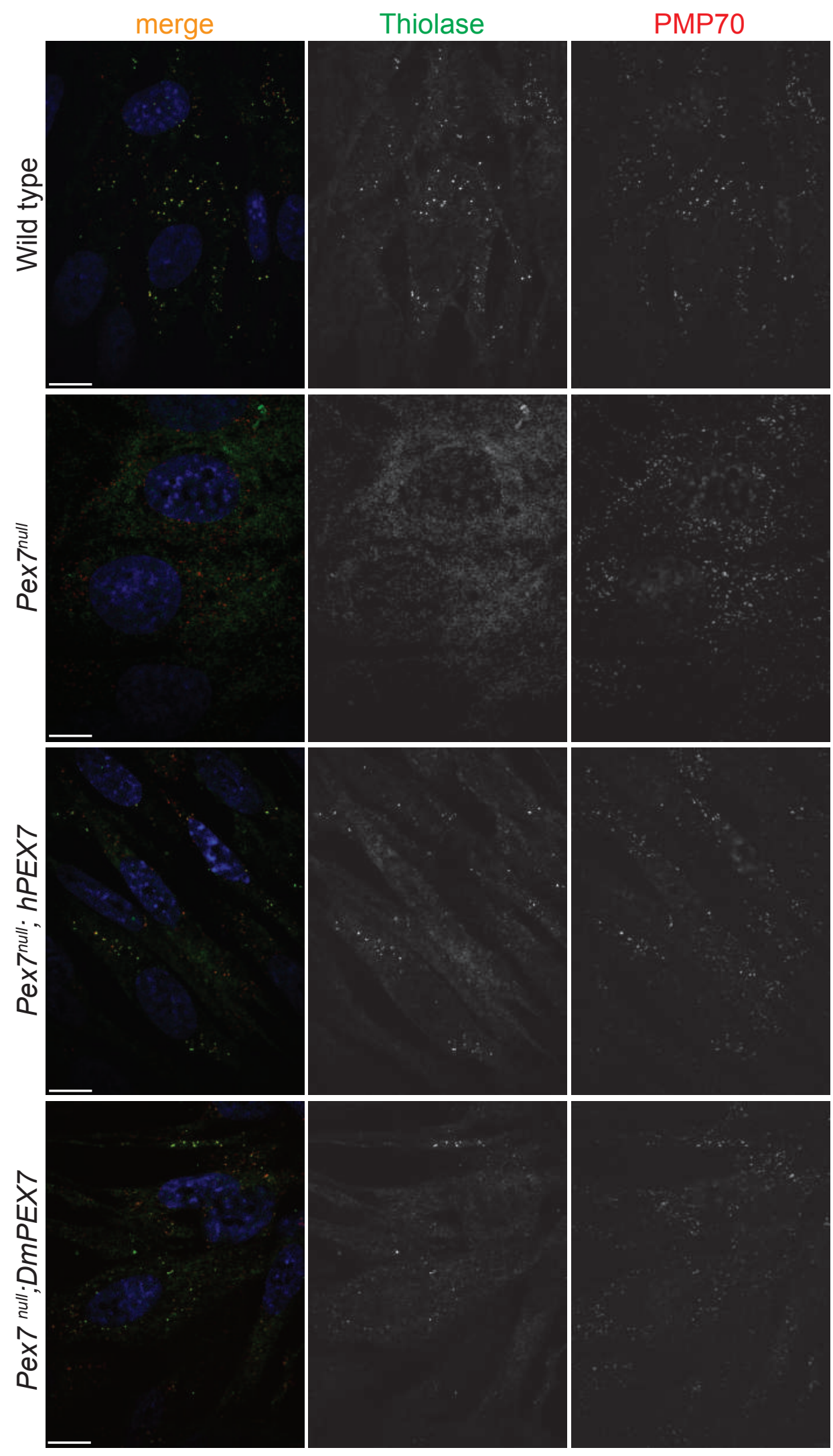

